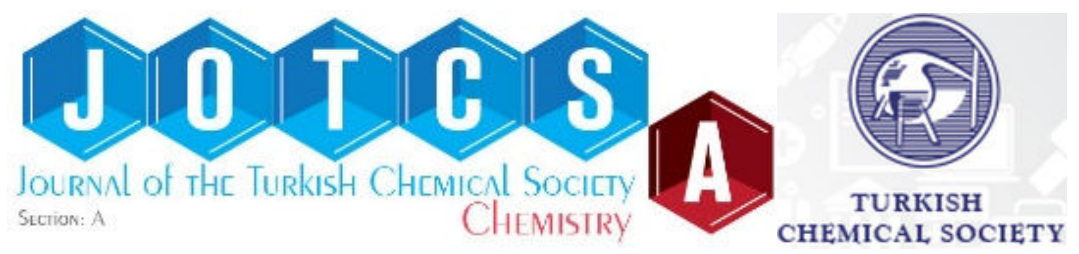

(This article was presented to the 28th National Chemistry Congress and submitted to JOTCSA as a full manuscript)

\title{
Chemical and Physical Investigations of Arabian Eye Kohl Brands as Cosmetic in Libya
}

Maher Mohamed Abed El-Aziza*, Mohamed Ammar Khalifab, Rabia Alhadi Gharianic, Hasan Daw Ashtawi Mohamed ${ }^{b}$, and Mahmud Ashtewi S. Ashtewi ${ }^{b}$

\author{
${ }^{a}$ Chemistry Department, Faculty of Education / Gaser Ben Ghashir, University of Tripoli, \\ Tripoli, Libya \\ ${ }^{b}$ Chemistry Department, Tarhuna Faculty of Arts and Sciences, Azzaytuna University, \\ Tarhuna, Libya \\ 'Janzour College of Education, Tripoli University, Tripoli, Libya \\ *Correspondence Author
}

\begin{abstract}
Three Arabian eye kohl brands were analyzed for the presence of lead and cadmium using atomic absorption spectroscopy (AAS) and X-ray diffraction techniques. In this work, the chemical analysis of the samples was studied according to the concentration of heavy metals, solubility in different medium, reaction with $\mathrm{KI}$, moisture, and organic contents. XRD pattern proposed the presence of some crystalline material in an amorphous background for all investigated brands. Mineral data analysis shows that the main minerals found in the samples are Manganoshadlunite in Natural Arab Kohl (NAK), samarskite in Natural Black Al-Athmod Kohl (NBAK), and kitaibelite in Black Al-Hashemi kohl (BHK). Physical properties such as color, forms, touch, and transparency are nearly the same for all samples but different in density, average pore diameter, and specific surface area. Atomic absorption spectroscopy (AAS) showed that the average percentage of $\mathrm{Pb}$ was in the range 0.2411 to $6.173 \%$; and from zero to $0.0019 \%$ for $\mathrm{Cd}$. The maximum concentration of $\mathrm{Pb}$ and Cd was found in Natural Arab Kohl (NAK) sample and is equal to $30.865 \mathrm{mg} / \mathrm{g}$ and 9.50 $\mu \mathrm{g} / \mathrm{g}$ respectively. The minimum concentration of heavy metal was found in Natural Black AlAthmod Kohl (NBAK) sample. Moisture was present in a very low percent $(\sim 1 \%)$ while organics was being in a reasonable amount (maximum $\geq 69 \%$ ). All eye kohl brands are soluble in acidic medium with different proportions and forms the yellow precipitate of $\mathrm{PbI}_{2}$ when react with $\mathrm{KI}$ which is considered as a chemical evidence for the presence of lead. It is highly recommended to use Natural Black Al-Athmod Kohl (NBAK) only because it has low concentration of heavy metals ( $\mathrm{Pb}$ and $\mathrm{Cd}$ ), and has higher specific surface area. The risk factor for using these type of eye kohl is very low. The higher surface area helps in spreading the active ingredient leading to increase the treatability against eye disease.
\end{abstract}

Keywords: Eye Kohl; lead; cadmium; Atomic Absorption Spectrophotometry (AAS). Cite this: Abed El-Aziz M, Ammar Khalifa M, Alhadi Ghariani R, Ashtawi Mohamed H, S. Ashtewi M. Chemical and Physical Investigations of Arabian Eye Kohl Brands as Cosmetic in Libya. JOTCSA. 2017;4(1):463-76.

DOI: To be assigned.

*Corresponding author. E-mail: hrshr152@gmail.com 


\section{INTRODUCTION}

Eye kohl has been used by girls and mature women in the Middle East, Far East and North Africa cosmetically for eye makeup in many occasions, eye kohl has also been used for eye treatments against some diseases. Traditionally, in many countries, eye kohl is applied to newborn children; parents believe it works against pain and evil eyes [1,2]. Most of the traditional eye kohl in Libyan markets comes from Africa, Asia and Middle East and all are made from stones contain elemental substances such lead, nickel, cadmium, and sulfur. Eye kohl is naturally occurring from the major amount of mineral sulfide, minor amount of mineral oxides and some of non-metals, especially carbon. The galena ore has a black-gray color with a shiny surface which is often used for making traditional eye kohl [1]. High considerations regarding the environment and human health in contact with heavy elements have been discussed, it has been reported that many medical products cause health risk and environmental contamination due to the presence of elements such as $\mathrm{Pb}, \mathrm{Hg}, \mathrm{Cd}$, and $\mathrm{Cr}$ [3]. Heavy metals such as cadmium, chromium, lead, and nickel are highly toxic to humans and cause acute symptoms like nausea, vomiting, headache, and can damage kidneys and the liver [4-6]. Several studies reported that a strong correlation between the use of eye kohl and $\mathrm{Pb}$ levels in the human body and its relation to many diseases [7-10]. Lead compounds are toxic by ingestion, inhalation, and by skin exposure. Children are more prone to be affected by $\mathrm{Pb}$ than adults [11]. Lead toxicity has terrible effects on both children and adult's health, including intelligent quotient deficit, behavior disorder, impaired hearing, and slowed growth [12-15]. Severe $\mathrm{Pb}$ poisoning resulting brain damage when blood $\mathrm{Pb}$ concentration is about $70 \mu \mathrm{g} / \mathrm{dL}$, the level usually proposed as the threshold for encephalopathy [16]. $\mathrm{Pb}$ replaces iron in blood, and more than $90 \%$ of $\mathrm{Pb}$ in the blood were found in the red cells and may cause severe illness, it has been reported that, in addition to other factors, a significant relation refers to the use eye kohl and the development of anemia $[17,18]$.

In recent studies, toxic heavy metals such as $\mathrm{Hg}, \mathrm{As}, \mathrm{Cr}$, $\mathrm{Se}$, and $\mathrm{Pb}$ have been detected quantitatively in eye cosmetic samples $[19,20]$. These studies highlight the toxicity and risk of using such products. Many studies were done in North Africa and in the Middle East regarding the composition of traditional eye kohl. Among these studies were conducted on 18 traditional eye kohl samples purchased from markets in Cairo, 6 samples were found to be mainly PbS [1]. In Oman, $47 \mathrm{kohl}$ samples were analyzed and reported that 14 of those sampled contain $\mathrm{Pb}$ in different concentrations [21]. Another study of 21 eye kohl samples was created in Saudi Arabia and Pb percentage was found between $2.9 \%$ and $34.1 \%$ in 4 
samples and more than $84 \%$ in 10 samples, while 7 samples did not contain $\mathrm{Pb}$ [22]. Eye kohl products were studied in Tunisia, it was reported that $\mathrm{Pb}$ concentrations ranged between $51.1 \mu \mathrm{g} / \mathrm{g}$ and $4839.5 \mu \mathrm{g} / \mathrm{g}$ while Cd concentrations ranged between $1.0 \mu \mathrm{g} / \mathrm{g}$ and $158.6 \mu \mathrm{g} / \mathrm{g}[23]$.

A research carried on a different samples of eye kohl collected from state of Libya, Egypt and Kingdom of Saudi Arabia (KSA) and the results indicate that kohl samples are contaminated with a significant concentrations of semi and heavy metals such as $\mathrm{As}, \mathrm{Cd}, \mathrm{Hg}$, and $\mathrm{Pb}$ [24]. In United Arab Emirates (UAE), a survey of minerals was carried out for 53 kohl samples. It was found that only 20 samples contain galena [25]. The above results were summarized in Table 1 which show that a significant difference in both chemical constituents and percent concentration of hazardous heavy metals between all samples investigated in many different countries, it is highly recommended to conduct further studies and researches in these fields. The present work aimed to investigate the physical and chemical characteristics of commercially available eye kohl samples commonly used by Libyan people as cosmetics. Physical investigations include the following: Density, particle radius, specific surface area, color, touch, forms, transparency and X-ray diffraction (XRD) analysis. Chemical investigations contain the analysis of lead and cadmium using atomic absorption spectroscopy (AAS), solubility in different medium, moisture contents, organic contents, and the effect of potassium iodide solution on the samples. 
Table 1. Concentration of heavy metals in different kohl samples from different Arab countries.

\begin{tabular}{|c|c|c|c|c|}
\hline Country & $\begin{array}{l}\text { No. of } \\
\text { kohl } \\
\text { samples }\end{array}$ & $\begin{array}{l}\text { Heavy metal } \\
\text { concentrations }\end{array}$ & Tools of analysis & $\begin{array}{l}\text { Reference } \\
\text { No. }\end{array}$ \\
\hline Cairo, Egypt & 18 & $\begin{array}{l}6 \text { samples contain galena } \\
10 \text { samples contain } \\
\text { amorphous carbon, calcite, } \\
\text { cuprite, goethite and talc. }\end{array}$ & $\begin{array}{l}\text { X-ray powder diffraction } \\
\text { (XRPD) } \\
\text { Scanning electron } \\
\text { microscope (SEM) }\end{array}$ & [1] \\
\hline Oman & 47 & $\begin{array}{l}14 \text { samples contain } \mathrm{Pb} \text { in } \\
\text { different concentrations. }\end{array}$ & $\begin{array}{l}\text { X-ray powder diffraction } \\
\text { (XRPD) } \\
\text { Scanning electron } \\
\text { microscope (SEM) }\end{array}$ & {$[21]$} \\
\hline $\begin{array}{l}\text { Kingdom of } \\
\text { Saudi Arabia } \\
\text { (KSA) }\end{array}$ & 21 & $\begin{array}{l}\mathrm{Pb}=2.9-34.1 \% \\
(4 \text { samples }) \\
\mathrm{Pb} \approx 84 \% \\
(10 \text { samples }) \\
\text { Nil } \\
\text { (7 samples) }\end{array}$ & $\begin{array}{l}\text { Energy dispersive X-ray } \\
\text { (EDXR) }\end{array}$ & {$[22]$} \\
\hline Tunisia & 11 & $\begin{array}{l}\text { Pb concentrations ranged } \\
\text { between } 51.1 \mu \mathrm{g} \mathrm{g}^{-1} \text { and } \\
4839.5 \mu \mathrm{g} \mathrm{g}^{-1} \text {. } \\
\text { Cd concentrations ranged } \\
\text { between } 1.0 \mu \mathrm{g} \mathrm{g}^{-1} \text { and } \\
158.6 \mu \mathrm{g} \mathrm{g}^{-1} \text {. } \\
\text { Cu concentrations ranged } \\
\text { between } 2.5 \mu \mathrm{g} \mathrm{g}^{-1} \text { and } \\
162.5 \mu \mathrm{g} \mathrm{g}^{-1} \text {. } \\
\text { Zn concentrations ranged } \\
\text { between } 0.7 \mu \mathrm{g} \mathrm{g}^{-1} \text { and } \\
185.0 \mu \mathrm{g} \mathrm{g}-1 .\end{array}$ & $\begin{array}{l}\text { Atomic absorption } \\
\text { spectrophotometer } \\
(\text { AAS })\end{array}$ & [23] \\
\hline $\begin{array}{l}\text { Libya, Egypt } \\
\text { and Kingdom of } \\
\text { Saudi Arabia } \\
\text { (KSA) }\end{array}$ & 8 & $\begin{array}{l}\text { Kohl samples are } \\
\text { contaminated with a } \\
\text { significant concentrations of } \\
\text { heavy metals } \mathrm{As}, \mathrm{Cd}, \mathrm{Hg} \text { and } \\
\mathrm{Pb}\end{array}$ & $\begin{array}{l}\text { Inductively coupled } \\
\text { plasma \& Optical emission } \\
\text { spectrometer } \\
\text { (ICP-OES) }\end{array}$ & [24] \\
\hline $\begin{array}{l}\text { United Arab } \\
\text { Emirates (UAE) }\end{array}$ & 53 & $\begin{array}{l}20 \text { samples contain galena } \\
33 \text { samples amorphous } \\
\text { carbon, calcite/aragonite, } \\
\text { hematite, goethite, sassolite, } \\
\text { talc and zincite }\end{array}$ & $\begin{array}{l}\text { X-ray powder diffraction } \\
\text { (XRPD) and } \\
\text { Scanning electron } \\
\text { microscope (SEM) }\end{array}$ & {$[25]$} \\
\hline $\begin{array}{l}\text { Galena }=\mathrm{PbS} \\
\text { Goethite }=\mathrm{FeO}(\mathrm{O}\end{array}$ & & $\begin{array}{ll}\text { /aragonite }=\mathrm{CaCO}_{3} & \text { Hemati } \\
\text { ite }=\mathrm{H}_{3} \mathrm{BO}_{3} & \text { Zincite }\end{array}$ & $\begin{array}{l}\text { Cuprite }=\mathrm{C} \\
\text { Talc }=\mathrm{Mg}_{3} \mathrm{~S}\end{array}$ & ${ }_{4}^{2} \mathrm{O}_{10}(\mathrm{OH})_{2}$ \\
\hline
\end{tabular}

\section{EXPERIMENTAL}

\section{Materials}

All chemicals used were of analytical grade. Three types of eye kohl samples are available and were purchased from the local Libyan market as a shiny black solid powder. All obtained samples were investigated without any further pre-chemical treatment. Because of the morphological appearance of all samples are nearly the same, eye kohl brands were labeled according to their local/public commercial names as follows: 


\begin{tabular}{lll}
\hline Common Arabic name & Symbol/Code & Brand \\
\hline Natural Arab Kohl & NAK & Local public \\
Natural Black Al-Athmod Kohl & NBAK & Local public \\
Black Al-Hashemi kohl & BHK & Local public \\
\hline
\end{tabular}

The above names of the three investigated kohl samples are pure Arabic common names related to the Arabic culture. These names were used by public to differentiate between the source, the quality or the type of the kohl which they would used.

\section{Instruments}

Determination of $\mathrm{Pb}$ and $\mathrm{Cd}$ in the obtained eye kohl samples was carried out using the Atomic Absorption Spectrophotometer (AAS) (VARIAN system, 220FS Model, Made in USA). $X$-ray diffraction (XRD) patterns and crystallinity measurements were obtained using a PHILIPS X-ray diffractometer, model PW 1890, with a nickel filter and a Cu- $\mathrm{K}_{\alpha}$ radiation.

\section{Measurements}

The radius of the particle of the sieved samples were determined according to El-Naggar method by measuring the diameter of 100 particles with an optical microscope. The particles were assumed to have a uniform spherical shape and a mean equivalent radius was calculated [26].

\section{Procedure}

The leaching process of lead and cadmium ions from solid eye kohl samples and preparation of $\mathrm{Pb}^{2+}$ and $\mathrm{Cd}^{2+}$ ion as concentrated solutions for analysis has been carried out according to the following steps:

1. Three times, 0.50 grams of each eye kohl sample were weighed and transferred into $100 \mathrm{~mL}$ beakers.

2. Concentrated solution of aqua regia containing a mixture of concentrated $\mathrm{HCl}$ and $\mathrm{HNO}_{3}$ (3:2 vol. / vol. ratio) was prepared and $10 \mathrm{~mL}$ of the mixture was added to each beaker.

3. Samples were gently heated to almost dryness on a hot plate in a good ventilation hood.

4. Again $10 \mathrm{~mL}$ of the concentrated aqua regia solution was added to each beaker and heated again to almost dryness.

5. Samples were left to cool, then the desired amount of doubly distilled water was added and stirred with a glass rod to dissolve the residue. 
6. Finally, dissolved samples were filtered into $50 \mathrm{~mL}$ volumetric flasks and completed to the mark with doubly distilled water.

7. The used glassware and filter papers were washed continuously with doubly distilled water to ensure that all $\mathrm{Pb}^{2+}$ and $\mathrm{Cd}^{2+}$ ions are completely leached from solid kohl samples.

8. The dissolved sample solutions were subjected directly to an air-acetylene flame atomic absorption spectrophotometer (UNICAM, 969) by the standard calibration technique for quantitative analysis.

9. Standardization and calibration curves take into consideration before measuring of $\mathrm{Pb}^{2+}$ and $\mathrm{Cd}^{2+}$ ions.

\section{RESULTS AND DISCUSSION}

Physicochemical characteristics of the three investigated eye kohl samples were presented in Tables 2 and 3. The physical properties include color, forms, bulk density, particle size, specific surface area, and crystallinity. While chemical analysis shows $\mathrm{Pb}$ and $\mathrm{Cd}$ contents, moisture content, organic content, reaction with $\mathrm{KI}$, chemical stability in different medium, and $\mathrm{pH}$ of the sample solution. A complete identification of any sample should contain chemical, physical and mineralogical investigation. The obtained results will be discussed in the following parts.

\section{Physical characteristics}

The physical properties of the investigated Libyan eye kohl samples were shown in Table 2, from which we can notice that all samples have nearly the same color and the predominant color is black which absorbs all the wavelengths of the sunlight. Shiny black color may be due to the presence of naturally occurring mineral sulfide galena or coal. Powdered granular forms in all samples also support the homogeneous chemical constituent's hypothesis. Bulk density measurements prove that Natural Arab Kohl sample is the heavier sample with the value equal to $\sim 3.53 \mathrm{~g} / \mathrm{mL}$. The bulk density sequence has the order: Natural Arab Kohl > Black Al-Hashemi Kohl > Natural Black Al-Athmod Kohl. These orders reflect the higher concentration of $\mathrm{Pb}(6.1730 \%)$ and lower carbon (organic) contents ( $\geq 60 \%$ ) in a Natural Arab Kohl sample as shown in Table 3. As a result, Natural Black Al-Athmod Kohl has low lead concentration $(0.2411 \%)$ and high carbon content ( $\geq 69 \%)$.

The particle size distribution shows that the average particle radius in $\mathrm{mm}$ are in the range from $0.12 \pm 0.03$ for NBAK sample to $0.18 \pm 0.03$ for NAK sample. The specific surface area 
in $\mathrm{m}^{2} / \mathrm{g}$ is in the range from 0.22 for NAK sample to 0.65 for NBAK sample. The data show that both the average particle radius and the specific surface area are in the opposite sequence:

The average particle radius: NBAK sample $<$ BHK sample $<$ NAK sample

The specific surface area: NBAK sample $>$ BHK sample $>$ NAK sample

Table 2. Physical characteristics of Libyan eye kohl samples.

\begin{tabular}{|c|c|c|c|}
\hline Item & NAK & NBAK & BHK \\
\hline Bulk density (g/c.c) & $\sim 3.53$ & $\sim 2.63$ & $\sim 2.78$ \\
\hline Average particle radius $(\mathrm{mm})$ & $0.18 \pm 0.03$ & $0.12 \pm 0.03$ & $0.16 \pm 0.03$ \\
\hline Specific surface area $\left(\mathrm{m}^{2} / \mathrm{g}\right)$ & 0.22 & 0.65 & 0.38 \\
\hline Color & Black / Gray & Shiny black & Shiny black \\
\hline Forms & Powdered granules & Powdered granules & Powdered granules \\
\hline Touch & $\begin{array}{l}\text { Greasy feel and stains } \\
\text { fingers and skin }\end{array}$ & $\begin{array}{l}\text { Greasy feel and } \\
\text { stains fingers and } \\
\text { skin }\end{array}$ & $\begin{array}{l}\text { Greasy feel and } \\
\text { stains fingers and } \\
\text { skin }\end{array}$ \\
\hline Transparency & Opaque & Opaque & Opaque \\
\hline XRD pattern & $\begin{array}{l}\text { Intensive continuum } \\
\text { peaks at low } 2 \theta \text { value }\end{array}$ & $\begin{array}{l}\text { Intensive continuum } \\
\text { peaks at low } 2 \theta \text { value }\end{array}$ & $\begin{array}{l}\text { Intensive continuum } \\
\text { peaks at low } 2 \theta \text { value }\end{array}$ \\
\hline
\end{tabular}

The above results were attributed to the fact that the higher surface area of the solid samples is associated with the lower particle radius and vice versa [27]. The values of average particle radius and the specific surface area of the Black Al-Hashemi Kohl sample is in between values of Natural Arab Kohl sample and Natural Black Al-Athmod Kohl sample.

X-ray diffraction pattern of the three investigated kohl samples was obtained along a wide range of $2 \theta$ degree and represented in Figure 1 , which shows two separate peaks of crystallinity, one of them is the intensive continuum peaks at very low $2 \theta$ value $(2 \theta=12.6$ degree, $\left.d=7.02 \mathrm{~A}^{\circ}\right)$ with relatively high intensity $(I=60-80 \%)$ for all investigated samples. Another peak at $2 \theta=25.3$ degree, $d=3.51 A^{\circ}$ with relatively low intensity ( $\left.I=10-30 \%\right)$. This reveals that some crystallinity was found and all samples contain crystalline materials in an amorphous background [28]. Mineral analysis for NAK sample $(\mathrm{Pb}=6.173 \%)$ shows the presence of Manganoshadlunite which has the empirical formula $\mathrm{Mn}^{2+}{ }_{0.75} \mathrm{~Pb}_{0.25} \mathrm{Cu}_{6} \mathrm{Fe}^{2+}{ }_{2} \mathrm{~S}_{8}$ at tolerance $=20 \%$. For NBAK sample $(\mathrm{Pb}=0.2411 \%)$, the major mineral found is samarskite with empirical formula Yb0.09 Er0.05 Y0.05 Dy0.05 Lu0.01 Ndo.01 Tm0.01 Ho0.01 Gdo.01 Sm0.008 Tb0.005 $\mathrm{Ce}_{0.004} \mathrm{Pr}_{0.001} \mathrm{La}_{0.001} \mathrm{U}_{0.12} \mathrm{Th}_{0.12} \mathrm{Ca}_{0.12} \mathrm{Fe}^{2+}{ }_{0.11} \mathrm{Mn}^{2+}{ }_{0.04} \mathrm{O}_{4}$. All metals in samarskite was found as oxides and the mineral has shiny black color as shown in Figure 2. The mineral composition of NBAK sample was obtained at tolerance $=20$. Finally, Figure 3 exhibits the shiny metallic lead gray color of kitaibelite which is the major mineralogical constituents of BHK sample $(\mathrm{Pb}=2.277 \%)$ at tolerance $=10 \%$. The empirical formula of kitaibelite is $\mathrm{Ag}_{10} \mathrm{PbBi}_{30} \mathrm{~S}_{51}$ [29]. From the above-mentioned results, it was noticed that the obtained amount of $\mathrm{Pb}$ from both 
chemical analysis by AAS and mineralogical analysis by XRD are closely related to each other and hence, the data analysis of XRD is in agreement with that of AAS for all investigated samples. In fact, mineralogical data analysis for $\mathrm{Cd}$ at trace concentration in eye kohl samples does not exhibit any specific major mineralogical constituents.

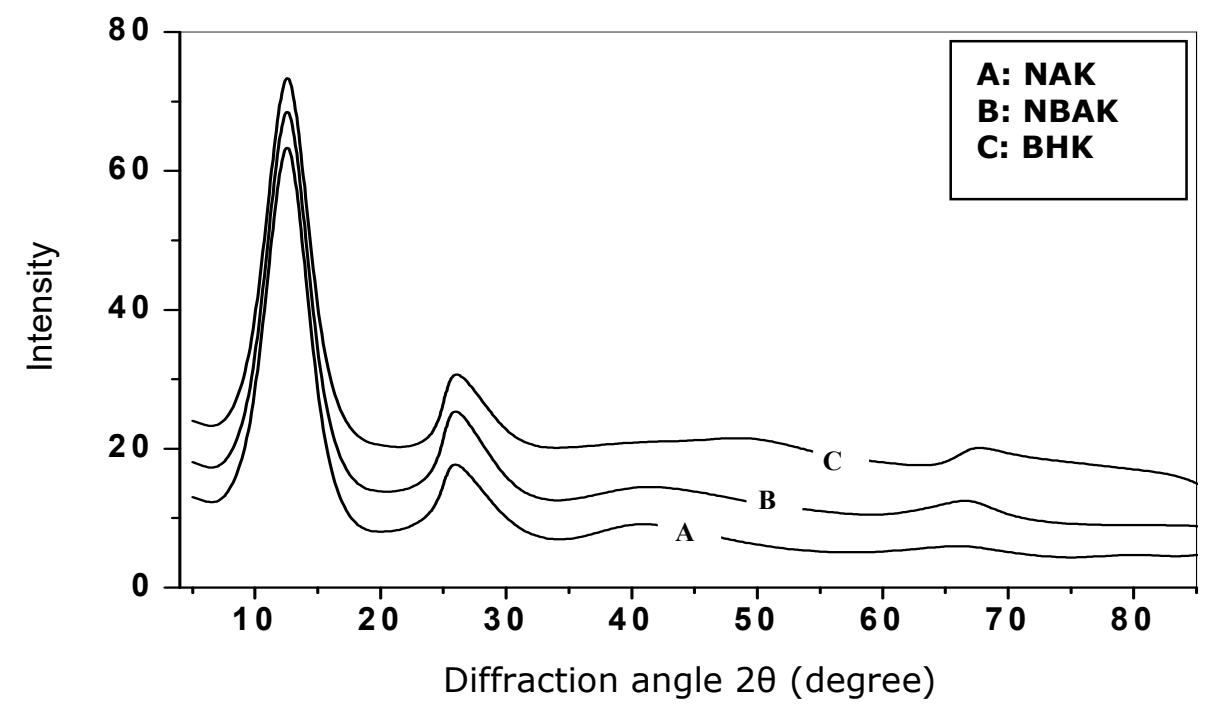

Fig. 1. XRD pattern for investigated Libyan eye kohl samples.

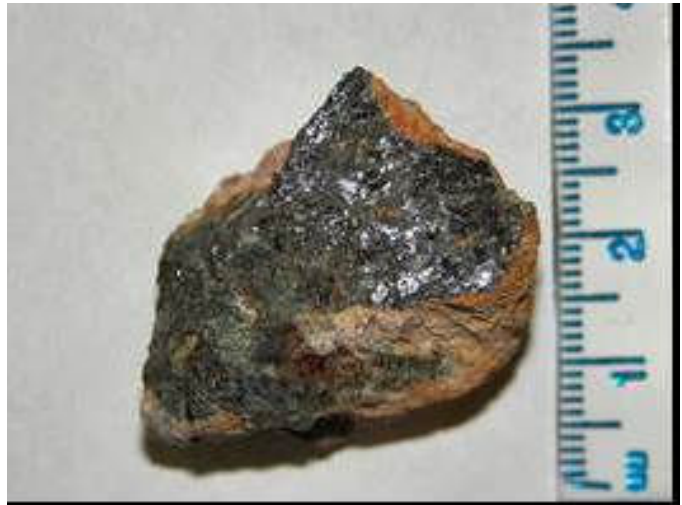

Fig. 2. Samarskite shiny black color

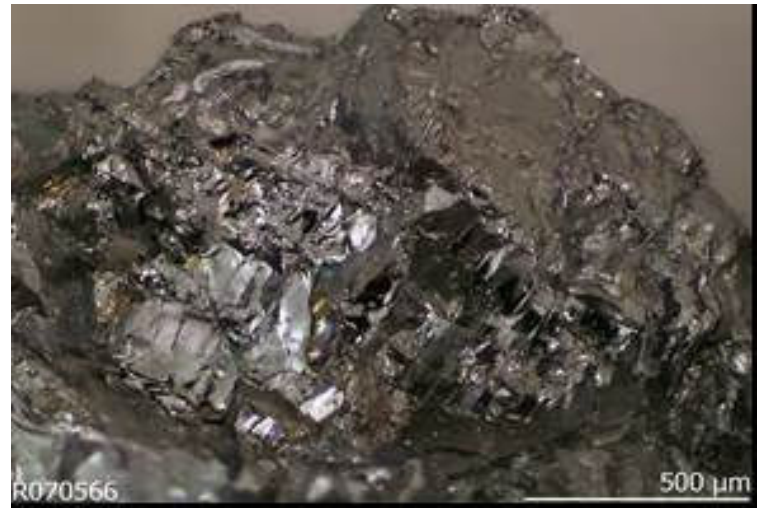

Fig. 3. Kitaibelite shiny metallic lead gray color

However, as shown in Table 2, all the investigated samples have the same general physical characteristics such as touch and transparency, they also have a greasy feeling in touching and stains fingers and skin while it is opaque. From the above-mentioned results, it can be concluded that Natural Arab Kohl has higher bulk density, higher particle size and lower specific surface area, but Natural Black Al-Athmod Kohl has a lower bulk density, lower particle size and higher specific surface area while Black Al-Hashemi Kohl is in between. 


\section{Chemical characteristics}

The chemical properties of eye kohl samples commonly used in Libya were investigated according to lead concentration, cadmium concentration, moisture content, organic content, solubility in different media, and the reaction with potassium iodide which give a characteristic intensive yellow color with $\mathrm{Pb}^{2+}$ ion. Chemical properties of the investigated samples were shown in Table 3, from which we can conclude that the highest concentration of $\mathrm{Pb}$ and $\mathrm{Cd}$ was found in Natural Arab Kohl samples. This result is in agreement with the bulk density measurements mentioned above. The density of $\mathrm{Pb}$ and $\mathrm{Cd}$ is equal to 11.34 and $8.65 \mathrm{~g} / \mathrm{mL}$, respectively, and hence the presence of heavy metals in a sample will raise its bulk density. The concentration of $\mathrm{Pb}$ takes the following order: Natural Arab Kohl sample $>$ Black Al-Hashemi Kohl sample > Natural Black Al-Athmod Kohl sample.

Table 3. Chemical characteristics of Libyan eye kohl samples.

\begin{tabular}{llll}
\hline Item & NAK & NBAK & BHK \\
\hline $\mathrm{Pb}(\% \mathrm{w} / \mathrm{w})$ & $6.1730 \%$ & $0.2411 \%$ & $2.2770 \%$ \\
$\mathrm{Cd}(\% \mathrm{w} / \mathrm{w})$ & $0.0019 \%$ & $\mathrm{Nil}$ & $0.0015 \%$ \\
$\mathrm{~Pb}$ concentration $(\mathrm{mg} / \mathrm{g})$ & 30.8650 & 1.2055 & 11.385 \\
$\mathrm{Cd}$ concentration $(\mu \mathrm{g} / \mathrm{g})$ & 9.50 & $\mathrm{Nil}$ & 7.50 \\
Reaction with KI & Yellow ppt. $(+++)$ & Yellow ppt. $(+)$ & Yellow ppt. $(+)$ \\
Moisture content $(\%)$ & $\sim 1.0 \%$ & $\sim 1.0 \%$ & $\sim 1.0 \%$ \\
Organic (carbon) content $(\%)$ & $\geq 60 \%$ & $\geq 69 \%$ & $\geq 65 \%$ \\
Solubility in $\mathrm{H}_{2} \mathrm{O}(\mathrm{cold}$ or hot) & - & - & - \\
Solubility in 3M HCl & ++ & + & + \\
Solubility in 3M HNO & ++ Cloudy solution & +++ & +++ \\
Solubility in aqua regia & ++++ & ++++ & ++++ \\
pH of solution & 7.9 & 7.3 & 7.4 \\
\hline
\end{tabular}

$(-)$ Insoluble $\quad(+)$ Sparingly soluble $\quad(++)$ Slightly soluble $\quad(+++)$ Soluble $\quad(++++)$ Highly soluble

It was calculated that for a Natural Arab Kohl sample, the concentration of $\mathrm{Pb}$ exceeded to the concentration of cadmium by about $\approx 3249$ times. For Black Al-Hashemi Kohl sample, the concentration of $\mathrm{Pb}$ exceeded to the concentration of $\mathrm{Cd}$ by about $\approx 1518$ times. $\mathrm{A}$ quantity of $\mathrm{Pb}$ in the samples is in tenths of milligrams per one-gram sample, while the quantity of $\mathrm{Cd}$ is in few micrograms per one-gram sample. The concentration of $\mathrm{Cd}$ is traced and in the range from 7.5 to $9.5 \mu \mathrm{g} / \mathrm{g}$ for Black Al-Hashemi Kohl sample and Natural Arab Kohl sample, respectively. These results refer to the lead is the main heavy metal affected on the chemical behavior of the eye kohl samples commonly used in Libya. The leached solution of three eye kohl samples was subjected to react with the potassium iodide solution and the preliminary tests show that the intense yellow color of lead iodide precipitate appeared with Natural Arab Kohl sample indicating to the presence of high lead 
concentration. On the other hand, pale yellow color which appearing with Natural Black AlAthmod Kohl sample and Black Al-Hashemi Kohl refers to the low concentration of $\mathrm{Pb}$ in these samples. The chemical reaction between lead ion as lead sulfide and potassium iodide can be expressed as follows:

$$
\begin{gathered}
\mathrm{PbS}_{(a q)}+2 \mathrm{KI}_{(a q)} \stackrel{\text { yields }}{\longrightarrow} \mathrm{PbI}_{2(s)} \downarrow+\mathrm{K}_{2} S_{(a q)} \\
\mathrm{Pb}\left(\mathrm{NO}_{3}\right)_{2(a q)}+2 \mathrm{KI}_{(a q)} \stackrel{\text { yields }}{\longrightarrow} \mathrm{PbI}_{2(s)} \downarrow+2 \mathrm{KNO}_{3(a q)}
\end{gathered}
$$

The moisture content does not exceed $\sim 1.0 \%$, which can be attributed to the physically adsorbed water on the sample surfaces. The carbon / organic content was in the range from 60 to $69 \%$, and the relative high carbon content reflects availability and durability of carbon material in the environment. In addition to the economic and commercial factors affecting on the public, industry of the eye kohl.

Solubility results show that all samples are insoluble in cold and hot water, but soluble in acidic medium especially aqua regia. Natural Black Al-Athmod Kohl Sample and Black AlHashemi Kohl is sparingly soluble in hydrochloric acid solution. Because of oxidation of sulfur ion $\left(\mathrm{S}^{2-}\right)$ to sulfur in the presence of nitric acid, Natural Arab Kohl sample forms cloudy solution with nitric acid, indicating the presence of $\mathrm{PbS}$ [30] in Natural Arab Kohl sample. The values of $\mathrm{pH}$ were measured for the aqueous solution of the investigated samples and the results show that the solutions are between neutral and slightly alkaline.

From Tables 1 and 2 and according to the above mentioned results, we can indicate that:

1) Natural Arab Kohl was characterized by high bulk density, high particle size, high concentration of heavy metals, small specific surface area, and finally low carbon content.

2) Natural Black Al-Athmod Kohl was characterized by low bulk density, small particle size, low concentration of heavy metals, big specific surface area, and finally high carbon content.

3) Black Al-Hashemi Kohl was characterized by a relatively mild physical and chemical properties. 


\section{CONCLUSION}

1) It is highly recommended that consumers use Natural Black Al-Athmod Kohl only because it has low concentration of heavy metals ( $\mathrm{Pb}$ and $\mathrm{Cd}$ ), and has a high specific surface area. The risk factor for using these type of eye kohl is very low. The higher surface area helps in spreading the active ingredient leading to increase the treatability against eye disease.

2) It is recommended that consumers avoid using Natural Arab Kohl and Black Al-Hashemi Kohl because these types of eye kohl have high concentrations of $\mathrm{Pb}$ and $\mathrm{Cd}$, and this increase the risk factor for human and the environment.

3) To complete the profile of eye kohl commonly used in Libya, it was recommended to continue the chemical and physical research by further tools.

\section{REFERENCES}

1. Hardy AD, Walton RI, Vaishnav R. Composition of eye cosmetics (kohls) used in Cairo. International Journal of Environmental Health Research. 2004 Feb;14(1):83-91.

DOI: $10.1080 / 09603120310001633859$.

2. Al-Ajel MM, Al-Ketbi MM, Al-Shehhi MA, Bastaki NA, Barss $P$, Grivna M, et al. Knowledge, Attitude \& Practice of Mothers Regarding Lead Poisoning due to Use of Kohl Eye Cosmetic for Babies in Al Ain, UAE. In: UAE University Research Conference (Senior \& Graduate Students). 2005. p. 1824.

3. AI-Saleh I, Coate L. Lead exposure in Saudi Arabia from the use of traditional cosmetics and medical remedies. Environmental Geochemistry and Health [Internet]. 1995 Mar [cited 2016 Dec 14];17(1). Available from: http://link.springer.com/10.1007/BF00188629.

4. Vaglenov A, Creus A, Laitchev S, Petkova V, Pavlova S, Marcos R. Occupational exposure to lead and induction of genetic damage. Environ Health Perspect. 2001 Mar;109(3):295-8.

URL: https://www.ncbi.nlm.nih.gov/pmc/articles/PMC1240249/.

5. Lobner D, Asrari M. Neurotoxicity of dental amalgam is mediated by zinc. Journal of dental research. 2003;82(3):243-246.

6. Patnaik P. A comprehensive guide to the hazardous properties of chemical substances. 3rd ed. Hoboken, NJ: John Wiley; 2007. 1059 p. ISBN: 978-0-471-71458-3.

7. Alkhawajah AM. Alkohl use in Saudi Arabia. Extent of use and possible lead toxicity. Trop Geogr Med. 1992 Oct;44(4):373-7. URL: http://europepmc.org/abstract/med/1295151.

8. Al-Saleh I, Nester M, Devol E, Shinwari N, Al-Shahria S. Determinants of Blood Lead Levels in Saudi Arabian Schoolgirls. International Journal of Occupational and Environmental Health. 1999 Apr;5(2):107-14. DOI: 10.1179/oeh.1999.5.2.107. 
9. Rahbar M, White F, Agboatwalla M, Hozhabri S, Luby S. Factors associated with elevated blood lead concentrations in children in Karachi, Pakistan. Bulletin of the World Health Organization. 2002;80(10):769-75. URL: http://www.scielosp.org/pdf/bwho/v80n10/8010a03.pdf.

10. Al-Ashban R., Aslam M, Shah A. Kohl (surma): a toxic traditional eye cosmetic study in Saudi Arabia. Public Health. 2004 Jun;118(4):292-8. DOI: 10.1016/j.puhe.2003.05.001.

11. Goyer R. Transplacental transport of lead. Environ Health Perspect. 1990;89:101-5.

URL: https://www.ncbi.nlm.nih.gov/pmc/articles/PMC1567784/.

12. Needleman HL, Schell A, Bellinger D, Leviton A, Allred EN. The Long-Term Effects of Exposure to Low Doses of Lead in Childhood: An 11-Year Follow-up Report. New England Journal of Medicine. 1990 Jan 11;322(2):83-8. DOI: 10.1056/NEJM199001113220203.

13. Schwartz J, Otto D. Lead and Minor Hearing Impairment. Archives of Environmental Health: An International Journal. 1991 Oct;46(5):300-5. DOI: 10.1080/00039896.1991.9934391.

14. Pocock SJ, Smith M, Baghurst P. Environmental lead and children's intelligence: a systematic review of the epidemiological evidence. BMJ. 1994 Nov 5;309(6963):1189-97.

DOI: $10.1136 / \mathrm{bmj} .309 .6963 .1189$.

15. Chukwuma CS. Environmental Lead Exposure in Africa. Ambio. 1997;26(6):399-403.

URL: http://www.jstor.org/stable/4314625.

16. Khayat A, Menon NS, Alidina MR. Acute lead encephalopathy in early infancy--clinical presentation and outcome. Ann Trop Paediatr. 1997 Mar;17(1):39-44.

DOI: $10.1080 / 02724936.1997 .11747861$.

17. Hidayat A, Weatherhead R, Al-Rajhi A, Johnson F. Conjunctival and lacrimal sac pigmentation by kohl (eyeliner). Br J Ophthalmol. 1997;81(5):418.

URL: https://www.ncbi.nlm.nih.gov/pmc/articles/PMC1722203/.

18. Lee IW, Ahn SK, Choi EH, Whang KK, Lee SH. Complications of eyelash and eyebrow tattooing: reports of 2 cases of pigment fanning. Cutis. 2001 Jul;68(1):53-5.

URL: http://europepmc.org/abstract/med/11480149.

19. Soruraddin MH, Heydari R, Puladvand M, Zahedi MM. A New Spectrophotometric Method for Determination of Selenium in Cosmetic and Pharmaceutical Preparations after Preconcentration with Cloud Point Extraction. International Journal of Analytical Chemistry. 2011;2011:1-8.

DOI: $10.1155 / 2011 / 729651$.

20. Hepp N, Mindak WR, Gasper JW, Thompson CB, Barrows JN. Survey of cosmetics for arsenic, cadmium, chromium, cobalt, lead, mercury, and nickel content. J Cosmet Sci [Internet]. 2014;65:125-

45.URL:https://www.researchgate.net/profile/William_Mindak/publication/264091887_Survey of_cosmetics_for_arsenic_cadmium_chromium_cobalt_lead_mercury_and_nickel_content/links /53fdf7170cf22f21c2f8be 3 b.pdf.

21. Hardy A., Vaishnav R, Al-Kharusi SS., Sutherland H., Worthing M. Composition of eye cosmetics (kohls) used in Oman. Journal of Ethnopharmacology. $1998 \mathrm{Apr} ; 60(3): 223-34$.

DOI: $10.1016 /$ S0378-8741(97)00156-6.

22. Al-Hazzaa SAF, Krahn PM. Kohl: a hazardous eyeliner. International Ophthalmology. 1995;19(2):83-8. DOI: 10.1007/BF00133177.

23. Nouioui MA, Mahjoubi S, Ghorbel A, Ben Haj Yahia M, Amira D, Ghorbel H, et al. Health Risk Assessment of Heavy Metals in Traditional Cosmetics Sold in Tunisian Local Markets. International Scholarly Research Notices. 2016;2016:1-12. DOI: 10.1155/2016/6296458. 
24. Sherif M, Orabi M, Abdulrahem O. Study of Heavy Elements and Radioactivity Concentrations in Some Eye Cosmetics Commonly Used in Arabic Regions. International Journal of Chemical Engineering and Applications. 2015 Feb;6(1):66-70. DOI: 10.7763/IJCEA.2015.V6.453.

25. Hardy AD, Walton RI, Myers KA, Vaishnav R. Availability and chemical composition of traditional eye cosmetics ("kohls") used in the United Arab Emirates of Dubai, Sharjah, Ajman, Umm AlQuwain, Ras Al-Khaimah, and Fujairah. J Cosmet Sci. 2006 Apr;57(2):107-25. URL: http://europepmc.org/abstract/med/16688375.

26. El-Naggar IM, Zakaria ES, Abou-Mesalam MM, Aly HF. Removal of some radioactive nuclides by insitu precipitation with ion exchange materials. Czechoslovak Journal of Physics. 1999 Jan;49(S1):951-8.. DOI: 10.1007/s10582-999-1023-2.

27. Dąbrowski A, Tertykh VA, editors. Adsorption on new and modified inorganic sorbents. Amsterdam; New York: Elsevier; 1996. 926 p. (Studies in surface science and catalysis). ISBN 0-444-82179-1.

28. El-Naggar I, Abdel-Galil E, Mahmoud M. Inorganic Ion Exchange Materials Based on Titanate: Synthesis, Characterization and Sorption Behaviour Of Zirconium Titanate for Some Hazardous Metal Ions from Aqueous Waste Solution. Isotope and Radiation Research. 2012;44(4):85171. URL: https://inis.iaea.org/search/search.aspx?orig_q=RN:44113183.

29. http://www.webmineral.com.

30. Pough FH, Scovil JA, National Audubon Society, National Wildlife Federation, Roger Tory Peterson Institute. A field guide to rocks and minerals. Boston: Houghton Mifflin; 1996. ISBN: 978-0395-72778-2. 
Türkçe Öz ve Anahtar Kelimeler

\title{
Libya'da Kozmetik Ürünü Olarak Kullanılan Arap "Eye Kohl" Markalarının Kimyasal ve Fiziksel İncelemesi
}

\author{
Maher Mohamed Abed El-Aziz, Mohamed Ammar Khalifa, Rabia Alhadi Ghariani, Hasan Daw \\ Ashtawi Mohamed, and Mahmud Ashtewi S. Ashtewi
}

Öz: Üç Arap "eye kohl" markası kurşun ve kadmiyum varlığı için atomik absorpsiyon spektroskopisi (AAS) ve X-ışını saçılması teknikleri ile incelenmiştir. Bu çalışmada, örneklerin kimyasal analizleri ağır metallerin derişimi, farklı ortamda çözünürlük, KI ile tepkime, nem ve organik içerik bakımından çalışılmıştır. XRD deseni bütün markalarda amorf artalan üzerinde bir kısım kristalize maddenin olduğunu göstermiştir. Mineral verilere göre örneklerde bulunan temel mineraller Manganoshadlunite (Natural Arab Koh., NAK), samarskit (Natural Black Al-Athmod Kohl, NBAK) ve kitaibelit (Black Al-Hashemi kohl, BHK) olarak bildirilmiştir. Renk, biçim, dokunuş ve şeffaflık bütün örneklerde neredeyse aynıdır, ancak yoğunluk, ortalama gözenek çapı ve özgül yüzey alanı bakımından farklılıklar göstermektedir. AAS'ye göre ortalama kurşun yüzdesi \%0,2411 ile \%6,173 arasındadır ve kadmiyum için yüzde değeri \%0,0019 olarak bulunmuştur. $\mathrm{Pb}$ ve Cd'nin maksimum derişimi NAK örneğinde sırasıyla $30,865 \mathrm{mg} / \mathrm{g}$ ve $9,50 \mu \mathrm{g} / \mathrm{g}$ olarak tespit edilmiştir. Ağır metaller bakımından en düşük derişim NBAK örneğinde bulunmuştur. Nem çok düşük bir yüzdede ( $\% 1$ ) bulunmuştur, ancak organik maddeler en fazla \%69'dan büyüktür. Bütün markalar asidik ortamda farklı oranlarda çözünmektedir ve KI ile tepkimeye sokulduğunda sarı renkli $\mathrm{PbI}_{2}$ katısı oluşturmaktadır, bu da kurşunun varlığı için delil olarak kullanılmıştır. İncelenen markalar arasında NBAK'ın kullanılması son derece isabetli olur, çünkü ağır metaller (Pb ve Cd) açısından düşük yüzdeye sahiptir ve özgül yüzey alanı daha yüksektir. Bu tür kozmetik ürününün kullanılmasındaki risk faktörü çok düşüktür. Yüksek yüzey alanı, göz hastalıklarına

karşı kullanılabilirlik olasılığını yükseltecek şekilde aktif içeriği yaymaktadır.

Anahtar kelimeler: "Eye kohl" kozmetik ürünleri; kurşun; kadmiyum; atomik absorpsiyon spektrometrisi (AAS). 